\title{
How Low Can They Go? Plant-Parasitic Nematode Distribution in a Washington Vineyard
}

\author{
Katherine E. East, ${ }^{1}$ \\ Michelle M. Moyer, ${ }^{1}$ \\ Nicholaus M. Madden, ${ }^{2}$ \\ and Inga A. Zasada ${ }^{3 *}$
}

Cite this article:

East KE, Moyer MM, Madden NM and Zasada IA. 2019. How low can they go? Plant-parasitic nematode distribution in a Washington vineyard. Catalyst 3:31-36.

'Department of Horticulture, Washington State University Irrigated Agriculture Research and Extension Center, Prosser, WA 99350; ${ }^{2}$ Vineyard Soil Technologies, Napa, CA 94558; and ${ }^{3}$ United States Department of AgricultureAgriculture Research Service (USDA-ARS), Horticultural Crops Research Laboratory, Corvallis, OR 97330.

${ }^{*}$ Corresponding author (inga.zasada@ars.usda.gov)

Manuscript submitted Jan 2019, revised June 2019, accepted July 2019

This is an open access article distributed under the CC BY license (https://creativecommons.org/ licenses/by/4.0/).

By downloading and/or receiving this article, you agree to the Disclaimer of Warranties and Liability. The full statement of the Disclaimers is available at https://www.asevcatalyst.org/ content/proprietary-rights-noticecatalyst. If you do not agree to the Disclaimers, do not download and/or accept this article.

doi: $10.5344 /$ catalyst.2019.19001

\section{Summary}

Goals: To map the distribution of two plant-parasitic nematode species, the northern root-knot nematode Meloidogyne hapla and the dagger nematode Xiphinema spp., in a Washington State winegrape vineyard slated for replanting. These nematode species can reduce vineyard longevity and weaken or kill young vines. Knowing how these nematodes are spatially distributed in soil can improve implementation of management strategies.

\section{Key Findings:}

- Northern root-knot nematode and dagger nematode had distinctly different distributions within the soil profile.

- Northern root-knot nematode was concentrated near the vine rows and dripirrigation lines, in the upper $61 \mathrm{~cm}$ (24 inches) of the soil profile. This is reflective of its life strategy, in which association with fine roots and areas of moisture is essential.

- Dagger nematode was relatively evenly distributed at all distances from the vine row, and significant populations were found down to the deepest sampling depth of $122 \mathrm{~cm}$ (48 inches). This demonstrates that it can survive readily on hosts other than grape and can parasitize root types that are not parasitized by northern root-knot nematode.

Impact and Significance: This work provides evidence for how and why nematode management practices may differ in their efficacy. Dagger nematodes were distributed throughout the sampled area and were found at depths that most fumigation efforts cannot reach. This increases the likelihood that dagger nematodes will recolonize treated areas, but this may take time as they move upward from deep in the soil. Root-knot nematodes may be more easily controlled via chemigation or fumigation, as their distribution corresponds to shallower areas with high fine root biomass wetted by drip irrigation.

Key words: dagger nematode, Meloidogyne hapla, root-knot nematode, spatial distribution, Vitis vinifera, Xiphinema

\section{Overview}

The Washington state winegrape industry is the second-largest in the United States and is of major economic importance to the state. While the industry is younger than other North American regions, vineyards in this region are reaching the age where replanting will soon be widespread. The majority of the industry is planted to self-rooted Vitis vinifera, which elicits concerns regarding plant-parasitic nematode management during replanting. $V$. vinifera is not inherently resistant to plant-parasitic nematodes, ${ }^{1}$ and given that most vineyards have a lifespan of 30 years or more, there is the potential for plantparasitic nematode populations to build up, which could drastically impact the success of a new planting. ${ }^{2}$

There are two major plant-parasitic nematodes of concern in Washington vineyards: the northern root-knot nematode, Meloidogyne hapla, and the dagger 
nematode, Xiphinema spp. (including X. rivesi and other members of the $X$. americanum species complex). ${ }^{3}$ The damage threshold for northern root-knot nematode is $100 \mathrm{~J} 2 / 250 \mathrm{~cm}^{3}$ soil (Santo, unpublished data), and for dagger nematode, 25 nematodes $/ 250 \mathrm{~cm}^{3}$ soil. ${ }^{4}$ Rootknot nematodes invade root tips as juveniles and develop into adults within. As adult females, their feeding creates giant cells in the roots, which can result in the development of a gall, or knot, and the removal of valuable carbohydrates from the plant. These nematodes also inhibit water and nutrient movement up the vine. Unlike root-knot nematodes, dagger nematodes do not invade the root. Dagger nematodes puncture root cells from the outside and remove cell contents through their stylet, a hollow needle-like mouthpiece. This direct vine damage is usually of little concern unless populations are high; however, some nematodes in the genus Xiphinema can transmit viruses through feeding, including Tomato ringspot virus, ${ }^{5}$ fortunately, this virus is not widespread in Washington vineyards. ${ }^{6}$ Dagger nematode species also differ from root-knot nematodes in where they are located in the soil, with major consequences on the efficacy of fumigation or other management practices. In previous work in Washington vineyards, dagger nematode was distributed randomly throughout vineyards, while root-knot nematode was associated with drip emitters under the vine row and concentrated in the upper 46 $\mathrm{cm}$ (18 inches) of the soil profile. ${ }^{7}$ However, in California, the opposite was found: $X$. americanum was found primarily in the upper $61 \mathrm{~cm}$ (24 inches) of soil in the vine row and Meloidogyne species were distributed to greater depths both within and between rows. ${ }^{8}$ Interestingly, Meloidogyne spp. had a similar distribution in relation to vine roots in both the Washington drip- and California furrow-irrigated vineyards. In both, the irrigation strategy (drip irrigation) modified where vine roots were distributed in soil.

In summer 2018, we were presented with a unique opportunity to more thoroughly characterize the distribution of northern root-knot and dagger nematodes in a vineyard slated for replanting. Over 140 soil samples were evaluated at this 115.5 -acre site, from seven blocks totaling 39.2 acres, collected from various distances between vine rows, and from depths down to $122 \mathrm{~cm} \mathrm{(48}$ inches; Figures 1 and 2), much deeper than the typical grower nematode sampling depth of $45 \mathrm{~cm}$ (18 inches). This opportunity was exceptional due to the fact that both nematodes were in moderate to high abundances (on average, 77 root-knot nematode J2 and 108 dagger nematodes $/ 250 \mathrm{~cm}^{3}$ soil, with maximum 1350 root-knot nematode $\mathrm{J} 2$ and 555 dagger nematodes $/ 250 \mathrm{~cm}^{3}$ soil).
There was an opportunity to collect many deep soil cores at a single site, just before replanting. Given the potential for widespread replanting across the state, with more vineyards facing this very scenario, this study provided data to assist in developing replanting plans when faced with nematode pressure.

\section{Major Observations and Interpretations}

Dagger nematode. The average dagger nematode population density across all samples was 108 nematodes $/ 250 \mathrm{~cm}^{3}$ soil. There was some variation between the seven blocks sampled, which ranged from 65 to 206

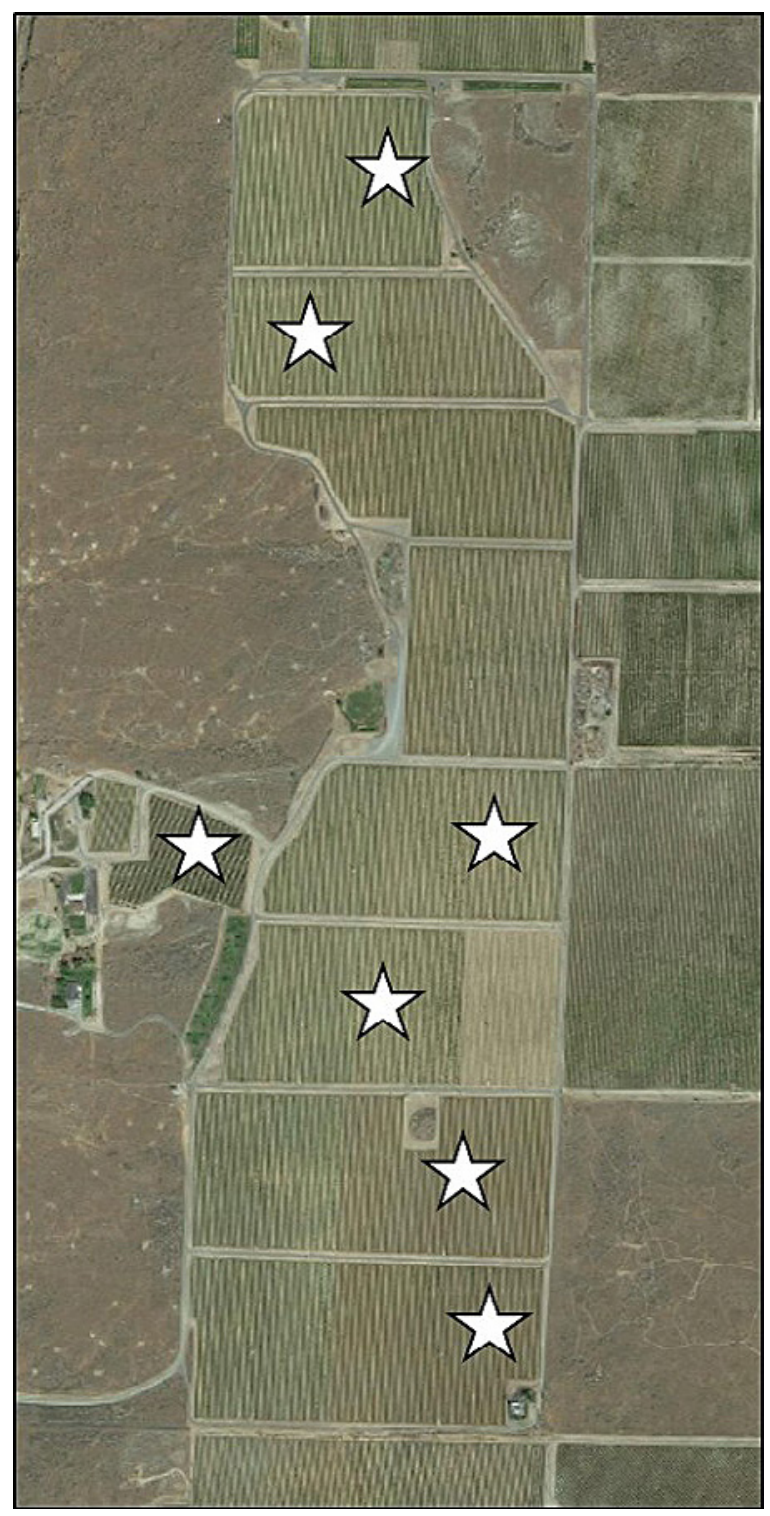

Figure 1 Aerial map of vineyard sampling area, with vineyard sampling locations indicated with white stars. Blocks sampled include Vitis vinifera cvs. Merlot, Cabernet Sauvignon, Syrah, and Malbec planted between 1990 and 2006. 
dagger nematodes $/ 250 \mathrm{~cm}^{3}$ soil, though all had similar distribution patterns. There were no major differences in dagger nematode density by depth $(p=0.073)$. They were also fairly evenly distributed throughout the entire sampling area (Figure 3), with the exception of more dagger nematodes under vines $(0.3 \mathrm{~m}$ or $1 \mathrm{foot}$ from vines) than at $0.9 \mathrm{~m}$ ( 3 feet) into the interrow, with intermediate numbers of dagger nematode at $1.5 \mathrm{~m}(5$ feet) in the center of the interrow $(p=0.005)$. This means

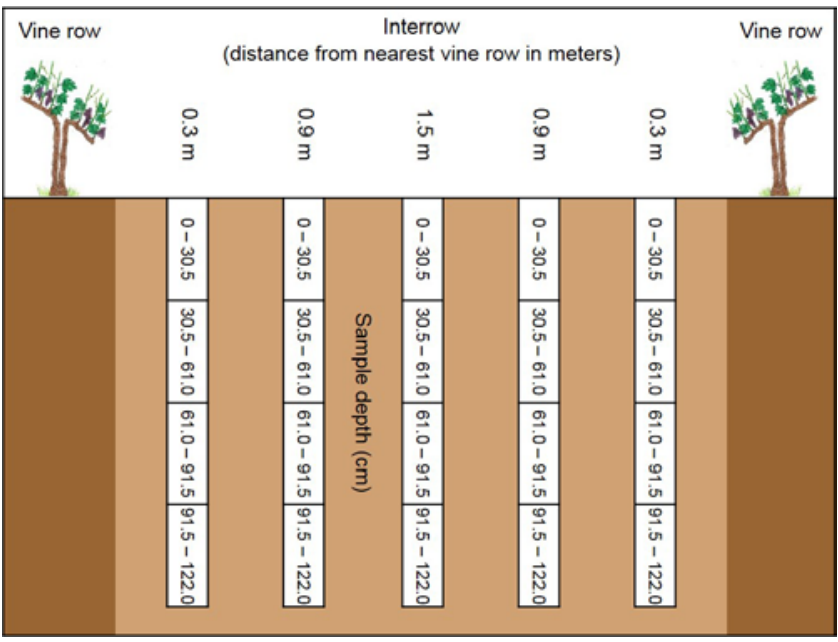

Figure 2 Soil sampling schematic for each vineyard location. Soil samples were deep-augured at $0.3,0.9$, or $1.5 \mathrm{~m}(1,3$, or 5 feet $)$ from vines between each of two vine rows, for a total of five sampling positions. Each sample was divided into four depths of $30.5 \mathrm{~cm}$ (12 inches) each, to a total depth of $122 \mathrm{~cm}$ (48 inches) in the soil profile.

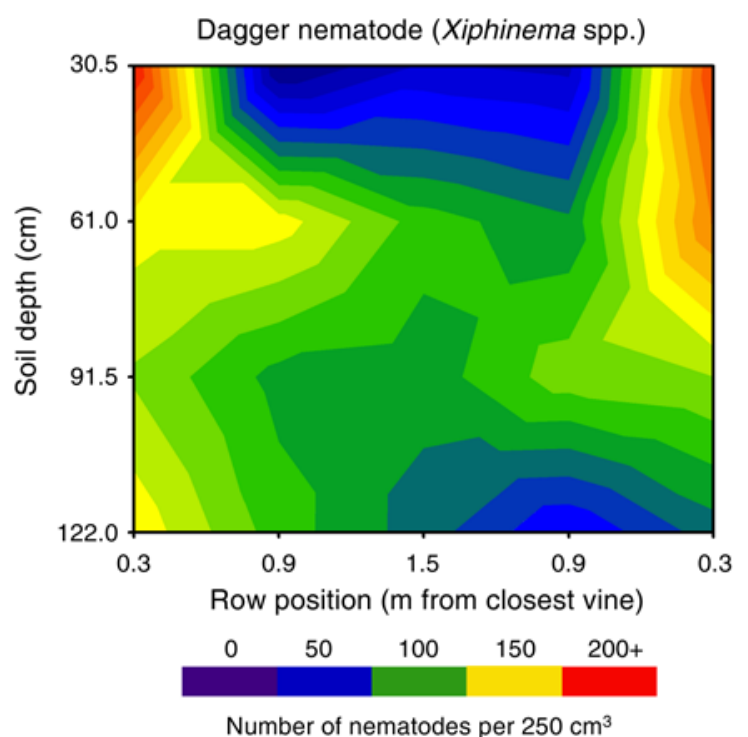

Figure 3 Contour map of dagger nematode (Xiphinema spp.) soil population densities (number per $250 \mathrm{~cm}^{3}$ soil) by soil depth $(30.5$, $61,91.5$, or $122 \mathrm{~cm}$ below the soil surface) and position $(0.3,0.9$, or $1.5 \mathrm{~m}$ from the vine row). Red indicates high population density and violet indicates low population density. that dagger nematodes are distributed relatively evenly throughout the soil profile, both to depths of $122 \mathrm{~cm} \mathrm{(48}$ inches) and across the area between rows.

Northern root-knot nematode. Northern root-knot nematode population densities, conversely, varied by depth ( $p=0.0001)$ and distance from the vine rows (position; $p<0.0001$; Figure 4). There were significantly more root-knot nematodes under vines (within $0.3 \mathrm{~m}$ from vine row; $p<0.0001$ ) than further into the interrow ( 0.9 and $1.5 \mathrm{~m}$ from vine row; $p=0.3196$ ). Under vines, there were more root-knot nematodes in the top 30.5 to $61 \mathrm{~cm}$ (12 to 24 inches) than in the bottom 91.5 to $122 \mathrm{~cm}$ (36 to 48 inches) of the soil profile. Root-knot nematode densities did not differ significantly between immediately adjacent depths (30.5 to 61, 61 to 91.5 , and 91.5 to 122 $\mathrm{cm} ; p=0.9799,0.077$, and 0.7359 , respectively), but did decline with increasing depths of $>30.5 \mathrm{~cm}$ (30.5 to 91.5 and 122,61 to $122 \mathrm{~cm} ; p<0.025$ and 0.0111 , respectively). As sampling moved further into the interrow, this effect lessened: at $0.9 \mathrm{~m}$ (3 feet) from the vine row, there were still more root-knot nematodes in the top $30.5 \mathrm{~cm}(12$ inches) than the bottom 91.5 to $122 \mathrm{~cm}$ (36 to 48 inches; $p<0.05$ ), but at $1.5 \mathrm{~m}$ (5 feet) from the vine row (the interrow middle), there was no longer a difference in nematode density at the different depths ( $p=0.8165)$. Previous work in Washington vineyards has shown that the majority of the fine roots and northern root-knot nematode densities are associated with the wetting zone of the drip emitters, which is generally concentrated in the top $61 \mathrm{~cm}$ (24 inches) of soil near vines, rather

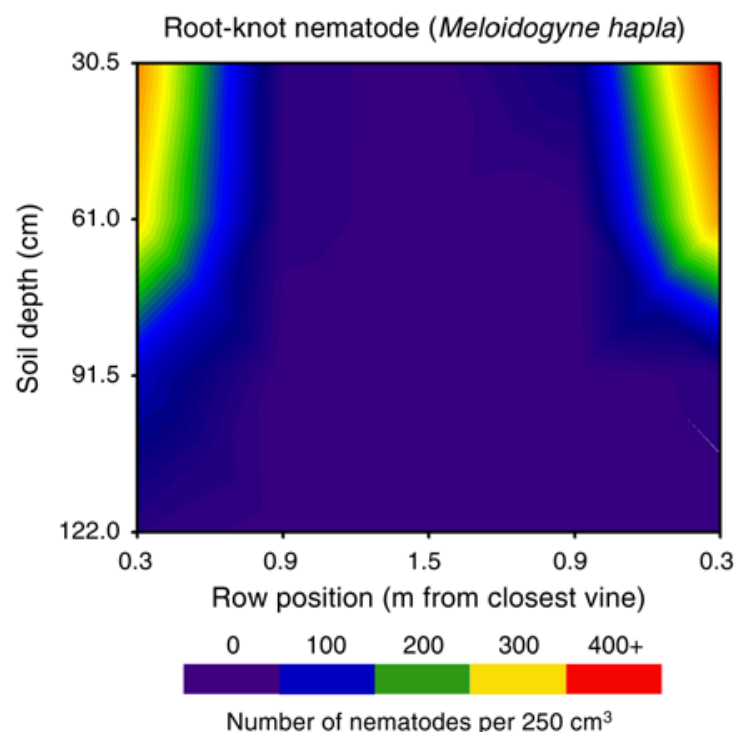

Figure 4 Contour map of northern root-knot nematode (Meloidogyne hapla) soil population densities (number per $250 \mathrm{~cm}^{3}$ soil) by soil depth $(30.5,61,91.5$, or $122 \mathrm{~cm}$ below the soil surface) and position $(0.3,0.9$, or $1.5 \mathrm{~m}$ from the vine row). Red indicates high population density and violet indicates low population density. 
than deeper in soil (depending on irrigation duration) or in between rows (where no water is being added). ${ }^{7}$ Soil compaction and temperature may also contribute to the lack of root-knot nematode between rows. The average root knot nematode density per sampled block ranged from 0 to $190 \mathrm{~J} 2 / 250 \mathrm{~cm}^{3}$ soil, all with similar distribution patterns. When considering only the top 61 $\mathrm{cm}$ of soil within $0.3 \mathrm{~m}$ from the vine row, which more accurately reflects what might be seen from a typical grower or consultant nematode sampling (24 inches deep, 1 foot from the vine row), the range increased from 0 to $862 \mathrm{~J} 2 / 250 \mathrm{~cm}^{3}$ soil.

There are two potential explanations for the difference in the distribution of the two nematode species in this vineyard. The first explanation may be disturbance. Dagger nematodes are known to be sensitive to disturbance due to their large body size and long life cycle. In controlled experiments, dagger nematode survival was favored when soil temperatures were constant and there were narrow changes in soil moisture. ${ }^{9}$ In a California vineyard, $X$. americanum was confined to the top $45 \mathrm{~cm}$ of undisturbed soil in the row. ${ }^{8}$ In this study, there were significantly fewer dagger nematodes between vine rows (at 0.9 and 1.5 $\mathrm{m})$ than near vine rows $(0.3 \mathrm{~m})$ in the top $30.5 \mathrm{~cm} \mathrm{(12}$ inches) of soil. The lower population densities of dagger nematode in the interrow may be due to a disturbed environment that undergoes extreme drying at certain times of the year, creating an environment less conducive for dagger nematode survival. This vineyard interrow was primarily native vegetation managed with mowing and typically going dormant during the summer months.

The second explanation may be the type of root material upon which the nematodes can feed. The northern root-knot nematode invades roots at the root tip, then migrates up the root and establishes a feeding site. ${ }^{10} \mathrm{An}$ area in the vineyard with abundant root tips, such as under emitters or near vines, ${ }^{7}$ makes an environment favorable for this nematode, as seen in this study. This was also demonstrated in an Australian vineyard, where population densities of an unknown root-knot nematode species (Meloidogyne spp.) were greatest close to vines and least in the alleyways. ${ }^{11}$ This is in contrast to dagger nematodes, which feed along roots, rather than at the tips. ${ }^{12}$ Once a dagger nematode has started feeding, it can continue to feed for several days at a single site. The widespread occurrence of dagger nematode deeper in the soil close to the vine row indicates that they are able to feed on grape roots that are functionally different from roots near the surface. Additionally, roots deep in the soil profile have a longer lifespan, potentially provid- ing the nematode with a prolonged source of material to feed upon. ${ }^{13}$

\section{Broader Impact}

Relatively unique in viticulture, the winegrape industry in Washington State is predominately planted to own-rooted $V$. vinifera, ${ }^{14}$ allowing for immediate retraining of grapevines following dormant cold temperature events. ${ }^{15}$ Unfortunately, this leaves Washington State growers vulnerable to plant-parasitic nematodes, as $V$. vinifera lacks resistance to many important species of these pests. ${ }^{1}$ As the industry begins the larger-scale process of replanting aging vineyards, growers will be faced with a decision to either: 1) use nematode-resistant rootstocks in these replant scenarios, potentially increasing the costs of vineyard replanting and retraining should a winter cold event occur; or 2) adopt chemical management strategies to reduce nematode populations or cultural strategies such as avoiding areas with high nematode densities. Nematode management will be critical for newly planted vines to establish a healthy root system prior to re-infestation of the planting site.

We found dagger nematodes in the soil to depths of at least $122 \mathrm{~cm}$ (48 inches), far deeper than the reach of most available fumigants. ${ }^{16}$ However, nematodes at those depths may take months to years to recolonize the treated soil areas, depending on the depth of the treated zone, allowing the vine adequate time to establish a healthy root system prior to infection. A different species of dagger nematode in southern Britain colonized areas at a rate of $30 \mathrm{~cm}$ (12 inches) per year and in drier, less hospitable soil, at a rate of $22 \mathrm{~cm}$ (9 inches) per year. ${ }^{17}$ Based on this, if soils were fumigated to a depth of $90 \mathrm{~cm}$ (36 inches), theoretically it could take two to three years for dagger nematodes to recolonize those areas, though there is no direct evidence of recolonization rates in vineyards under these conditions. Dagger nematodes were also present to some degree across vineyard rows. This distribution of dagger nematode between vine rows may reduce the efficacy of shifting planting location (i.e., row placement) during vineyard establishment to avoid this nematode. Coupled with the added cost of re-establishing vineyard infrastructure when row-shifts are adopted, it could be difficult to justify this cultural practice as the only means for dagger nematode management.

We found the northern root-knot nematode more localized than the dagger nematode, at shallow depths within the vine row, although it too was found at depths up to $122 \mathrm{~cm}$ (48 inches). This is supported by other distribution studies of the root-knot nematode in drip- 
irrigated vineyards, where root-knot nematodes were found directly under drip emitters where the majority of vine fine roots are also located. ${ }^{7}$ In this study, northern root-knot nematode was most often found in the top 61 $\mathrm{cm}$ (24 inches) of the vineyard soil and within $30.5 \mathrm{~cm}$ (12 inches) of the planted vine row. This is within the typical depth and distance from the vine row recommended to growers in Washington State for nematode sampling. ${ }^{18}$ This would make the efficacy of fumigation seem likely. However, if a fumigant is applied through the existing dripline, as in the scenario where the existing vineyard infrastructure is maintained while replanting, then great care will be needed to ensure uniform distribution of the fumigant. There are many factors that can affect the uniformity of distribution of fumigants applied through the drip-irrigation system, including water application rate, soil type, temperature, and product solubility. ${ }^{19}$ If the application is not uniform, surviving root-knot nematodes could quickly invade the newly-planted grapevine roots. Additionally, infected vine roots remaining after the removal of a vineyard may protect root-knot nematodes from fumigation, as some fumigants applied at rates appropriate for plant-parasitic nematodes in soil are not effective on endoparasite nematodes protected in root tissues. ${ }^{20} \mathrm{In}$ Washington, given that the primary concern is the risk potential of root-knot nematode infection, great care should be taken to ensure that pre-planting fumigation is evenly distributed across the treated site and that adequate removal of old roots has occurred. An additional cultural practice that may help manage northern rootknot nematode in vineyard replant scenarios would be to establish new rows in the previous interrows, which would help to avoid planting directly into high-nematode-density soil. As noted above, however, this strategy would not work for avoiding dagger nematodes if present, and moving the infrastructure creates additional costs for replanting a vineyard.

This study examined the depth and distribution of two plant-parasitic nematodes that are of concern to Washington winegrape growers. This new knowledge will help inform decisions about pre-plant fumigation and post-plant nematicide applications, particularly as it relates to their ability to reach all depths and locations where potential target nematodes may reside. It will also help inform and optimize replanting decisions regarding maintaining existing vineyard infrastructure (i.e., how that might affect management efficacy), as well as pre-plant fumigation or post-plant nematicide application methods (e.g., application through the existing dripline, direct soil injection, or broadcast application).

\section{Experimental Design}

Soil sampling. A commercial vineyard in the Red Mountain American Viticultural Area $\left(46^{\circ} 16^{\prime} \mathrm{N}\right.$; $119^{\circ} 27^{\prime} \mathrm{W}$ ) in Washington State, known to have plantparasitic nematodes, was sampled (Figure 1). The total acreage of the vineyard was 115.5 acres planted with a diversity of own-rooted $V$. vinifera varieties managed under drip irrigation (Nebbiolo, Sauvignon blanc, Semillon, Syrah, Cabernet Sauvignon, Merlot, and Malbec). Vines were established on virgin ground at this site between 1985 and 2001; one block was replanted to Cabernet Sauvignon in 2012. The soil types across the vineyard are a Warden silt loam with 0 to $30 \%$ slope and a Scooteney silt loam with 0 to $5 \%$ slope. Within this vineyard, seven blocks were chosen for coring. The primary intention was to determine the distribution of soluble salts beneath the vines and in the interrows, and coring samples were designed for such; determining nematode population densities was the secondary intention.

Sampling occurred on 23 April 2018. The vineyard interrow was primarily managed with native vegetation, mowing, and no water application. Sampling occurred in this vineyard before any replant preparation had occurred: no major soil or vine disturbance had occurred in the vineyard prior to soil sampling. The vineyard rows were sampled by auger at five locations over the span of the $3 \mathrm{~m}$ wide rows (Figure 2). These five sample distances were $0.3 \mathrm{~m}$ from the starting vine $(2.7 \mathrm{~m}$ from the vine across the row), $0.9 \mathrm{~m}$ from the starting vine (2.1 $\mathrm{m}$ from the vine across the row), $1.5 \mathrm{~m}$ from the starting vine (middle of row), $2.1 \mathrm{~m}$ from the starting vine ( $0.9 \mathrm{~m}$ from the vine across the row), and $2.7 \mathrm{~m}$ from the starting vine $(0.3 \mathrm{~m}$ from the vine across the row $)$. As such, the $2.1 \mathrm{~m}$ and $2.7 \mathrm{~m}$ sampling locations were the same distance from a vine row as the $0.3 \mathrm{~m}$ and 0.9 $\mathrm{m}$ sampling distances. The depth of each sample was in $30.5 \mathrm{~cm}$ increments to a depth of $122 \mathrm{~cm}(12$ inch increments to 48 inches deep; four sampling depths total). Therefore, 140 soil samples (seven vineyard blocks $\times$ five distances between vines $\times$ four depths) were collected across the sampling locations. After samples were processed for soil chemical analysis (data not included), a $250 \mathrm{~cm}^{3}$ subsample was collected and used for nematode extraction, as described below.

Nematode extraction and enumeration. Samples were placed in a cooler and transported to the laboratory for plant-parasitic nematode extraction. Nematodes were extracted from $250 \mathrm{~cm}^{3}$ soil using a semi-automatic elutriator. ${ }^{21}$ Nematodes were captured on a $37 \mu \mathrm{m}$ sieve and backwashed into a $50 \mathrm{~mL}$ Eppendorf tube; samples were 
cleared of debris using a sucrose centrifugation-flotation technique. ${ }^{22}$ Extracted plant-parasitic nematodes were counted from a $1 \mathrm{~mL}$ aliquot of the cleared sample under a Leica DM IL inverted microscope (Leica Microsystems). Population densities of northern root-knot (M. hapla) and dagger (Xiphinema sp.) nematodes are expressed as number of nematodes per $250 \mathrm{~cm}^{3}$ soil.

Statistical analysis. Nematode data are presented as counts per $250 \mathrm{~cm}^{3}$ soil. As data were non-normally distributed, non-parametric tests were used. Nematode data were ranked and analyzed using the Fit Model platform in JMP (ver. 13.0.0, SAS Institute, Inc.) using standard least squares with position, depth, and position $\times$ depth as fixed effects, and block as a random effect. There was no significant interaction between position and depth, so effect of position and depth on nematode density was examined non-parametrically using the Kruskal-Wallis Test. Pairwise comparisons were performed using the non-parametric Steel-Dwass Method.

\section{References and Footnotes}

1. Howland AD, Skinkis PA, Wilson JH, Riga E, Pinkerton JN, Schreiner RP and Zasada IA. 2015. Impact of grapevine (Vitis vinifera) varieties on reproduction of the northern root-knot nematode (Meloidogyne hapla). J Nematol 47:141-147.

2. McKenry MV, Kretsch JO and Anwar SA. 2001. Interactions of selected Vitis cultivars with endoparasitic nematodes. Am J Enol Vitic 52:310-316.

3. Akinbade SA, Mojtahedi H, Guerra L, Eastwell K, Villamor DEV, Handoo ZA and Skantar AM. 2014. First report of Xiphinema rivesi (Nematoda, Longidoridae) in Washington state. Plant Dis 98:1018.

Zasada IA, Riga E, Pinkerton JN, Wilson JH and Schreiner RP. 2012. Plant-parasitic nematodes associated with grapevines, Vitis vinifera, in Washington and Idaho. Am J Enol Vitic 63:522-528.

Zasada IA, Peetz A, Howe DK, Wilhelm LJ, Cheam D, Denver DR and Smythe AB. 2014. Using mitogenomic and nuclear ribosomal sequence data to investigate the phylogeny of the Xiphinema americanum species complex. PLoS ONE 9: e90035.

4. McKenry MV. 1992. Nematodes. In Grape Pest Management. 2d ed. Flaherty DL et al. (eds.), pp. 281-285. Publication 3343. Division of Agriculture and Natural Resources, University of California, Oakland.

5. Brown DJF, Halbrendt JM, Jones AT, Vrain TC and Robbins RT. 1994. Transmission of three North American nepoviruses by populations of four distinct species of the Xiphinema americanum group. Phytopathol 84:646-649.

6. Martin RR, Eastwell KC, Wagner A, Lamprecht S and Tzanetakis IE. 2005. Survey for viruses of grapevine in Oregon and Washington. Plant Dis 89:763-766.

7. Howland AD, Schreiner RP and Zasada IA. 2014. Spatial distribution of plant-parasitic nematodes in semi-arid Vitis vinifera vineyards in Washington. J Nematol 46:321-330.
8. Ferris H and McKenry MV. 1974. Seasonal fluctuations in the spatial distribution of nematode populations in a California vineyard. J Nematol 6:203-210.

9. Lownsbery BF and Maggenti AR. 1963. Some effects of soil temperature on population levels of Xiphinema americanum. Phytopathology 53:667-668.

10. Taylor AL and Sasser JN. 1978. Biology, Identification and Control of Root-Knot Nematodes (Meloidogyne Species). North Carolina State University, North Carolina.

11. Quader M, Riley IT and Walker GE. 2001. Distribution pattern of root-knot nematodes (Meloidogyne spp.) in South Australian vineyards. Australas Plant Path 30:357-360.

12. Cohn E. 1970. Observations on the feeding and symptomology of Xiphinema and Longidorus on selected host roots. J Nematol 2:167-173.

13. Anderson LJ, Comas LH, Lakso AN and Eissenstat DM. 2003. Multiple risk factors in root survivorship: A 4-year study in Concord grape. New Phytol 158:489-501.

14. Moyer M and O’Neal S. 2014. Pest Management Strategic Plan for Washington State Wine Grape Production. US Dept. Agric., Office of Pest Management Policy. https://ipmdata.ipmcenters. org/documents/pmsps/WA_WineGrape_PMSP_2014.pdf.

15. Moyer MM, Mills LJ, Keller M and Hoheisel G. 2011. Assessing and managing cold damage in Washington vineyards. Publication \#EM0423. Washington State University Extension Publishing. Pullman, WA.

16. Ajwa HA and Trout T. 2000. Distribution of drip applied fumigants under various conditions. In Annual International Research Conference on Methyl Bromide Alternatives and Emissions Reductions. South Atlantic Area-Wide Pest Management Project for Methyl Bromide Alternatives, Universtiy of Florida, Gainesville, FL. https://mbao.org/static/docs/ confs/2000-orlando/papers/59ajwa.pdf.

Ajwa HA and Trout T. 2004. Drip application of alternative fumigants to methyl bromide for strawberry production. HortScience 39:1707-1715.

17. Harrison BD and Winslow RD. 1961. Laboratory and field studies on the relation of arabis mosaic virus to its nematode vector Xiphinema diversicaudatum (Micoletzky). Ann Appl Biol 49:621-633.

18. Moyer MM and O'Neal SD. 2013. Field Guide for Integrated Pest Management in Pacific Northwest Vineyards. Pacific Northwest Extension Publication \#PNW644. Washington State University Extension Publishing, Pullman, WA.

19. Ajwa HA, Trout T, Mueller J, Wilhelm S, Nelson SD, Soppe R and Shatley D. 2002. Application of alternative fumigants through drip irrigation systems. Phytopathology 92:1349-1355.

20. McKenry MV, Thomason IJ and Naylor P. 1977. Dosageresponse of root-knot nematode-infected grape roots to cis1,3-dichloropropene. Phytopathology 67:709-711.

Zasada IA, Halbrendt JM, Kokalis-Burelle N, LaMondia J, McKenry MV and Noling JW. 2010. Managing nematodes without methyl bromide. Annu Rev Phytopathol 48:311-328.

21. Seinhorst JW. 1962. Modifications of the elutriation method for extracting nematodes from soil. Nematologica 8:117-128.

22. Jenkins WR. 1964. A rapid centrifugal-flotation technique for separating nematodes from soil. Plant Dis Rep 48:692. 